\title{
ОТНОШЕНИЯ РОССИИ С ЧЕРНОГОРИЕЙ В ГОДЫ ПРАВЛЕНИЯ ЕЛИЗАВЕТЫ ПЕТРОВНЫ
}

\section{RELATIONS BETWEEN RUSSIA AND MONTENEGRO DURING THE REIGN OF ELIZABETH PETROVNA}

\section{T. Ershova \\ A. Afanaseva}

Summary: The article is devoted to the relations between Russia and Montenegro during the reign of Elizabeth Petrovna (1741-1761). The article shows the Russian-Montenegrin socio-political and church relations. The article analyzes the factors that influenced the uneven development of Russian-Montenegrin relations in the XVIII century. The place of Montenegrins in the Balkan politics of Russia is revealed.

Keywords: Elizaveta Petrovna, Montenegrins, Russia and Montenegro, Russian-Montenegrin relations, XVIII century.
Ершова Тамара Витальевна

Д.и.н., профессор, Московский городской педагогический университет ershtamaris@yandex.ru

Афанасьева Алла Анатольевна Аспирант, Московский городской педагогический университет altmans@mail.ru

Аннотация: Статья посвящена отношениям России с Черногорией в годы царствования Елизаветы Петровны (1741-1761). В статье показаны русскочерногорские общественно-политические и церковные связи. Анализируются факторы, повлиявшие на неравномерный характер развития русскочерногорских отношений в XVIII веке. Раскрывается место черногорцев в балканской политике России.

Ключевые слова: Елизавета Петровна, черногорцы, Россия и Черногория, русско-черногорские отношения, XVIII век.
$\Pi$ оворотным моментом в развитии русско-черногорских отношений явилось обращение российского самодержца Петра I накануне Прутского похода (1711 г.) к балканским христианам с призывом выступить в союзе с Россией против Турции. Прибытие в Черногорию русских эмиссаров, доставивших царскую грамоту и деньги, пожалованные черногорцам как союзникам, участие черногорцев на стороне России в войне с Турцией, а затем прибытие в Санкт-Петербург в 1715 г. черногорского митрополита Данилы Петровича Негоша стали важными событиями в истории русско-черногорских политических связей петровской эпохи.

В петровскую эпоху Черногория получила вместе с материальной помощью подтверждение того, что в лице России она обрела надежного союзника и мощного покровителя. Однако, несмотря на совпадение политических интересов, рядом факторов была обусловлена последующая неравномерность дальнейших взаимоотношений Черногории и России. Свою роль сыграли географическая удаленность, геополитическое положение и существенная разница в размерах территорий данных государств. Уже в первые годы после установления политических связей с Россией Черногория пыталась найти поддержку в борьбе против турок у других держав. Несмотря на воодушевление, которое у черногорцев вызвали результаты визита митрополита Данилы в Петербург, владыка быстро пошел на сближение с Австрией и Венецией. Подобные решения, приносившие сиюминутную выгоду, будут принимать и последующие правители Черногории. Черногорские историки объяс- няют это тяжелыми обстоятельствами, в которых находился их народ, и называют Венецианскую республику ближайшим соседом, от которого можно было получить материальную помощь. В современной черногорской историографии указывается даже на то, что сравнительно быстрый поворот владыки Данилы к Венеции после его возвращения из России произошел ввиду недостаточности материальной помощи со стороны России. Так, Р. Распопович пишет, что денег, которые владыка Данила привез в Черногорию из России, не хватало на восстановление разоренных территорий, разрушенных церквей и монастырей, на погашение военных расходов и долгов [7: с. 20-21].

По свидетельству митрополита Савы Петровича, пожалованные Даниле 5000 рублей были розданы разоренным черногорцам, а другие 5000 рублей были израсходованы не на ремонт церквей, а на покрытие долгов и выкуп пленных, на что было потрачено немало и собственных денег владыки. По свидетельству же Захария Орфелина, пожалованные российской стороной деньги оставались в руках владык и почти не доходили до мирян. Даже не все воеводы получили причитавшиеся им медали с царским портретом, так как значительная их часть осталась у Данилы, а затем досталась его преемникам. Медали переплавили в золото, которое владыка Василие обменял на венецианские цекины [5: с. 88].

В октябре 1725 г. митрополит Данила в письме к Г.И. Головкину, выражая соболезнование по поводу смерти императора Петра I, просил не прекращать вы- 
плату субсидии Цетинскому монастырю [6: с. 58-59, 72, 73]. После смерти Петра I правительство России проводило пассивную политику в отношении Черногории. С восшествием на престол Елизаветы Петровны (17411761) политические связи между Россией и Черногорией начинают восстанавливаться и расширяться.

Причина невыплаты до 1741 года назначенных Петром I субсидий для Цетинского монастыря заключалась не только в сложившейся внутриполитической ситуации в России. В указе Петра І от 1715 г. говорилось о том, чтобы из черногорско-приморской митрополии и Цетинского монастыря приезжали в Москву и «в Петербург ко двору каждый третий год за милостыней, которую предписывалось отправлять в тот монастырь в эти годы по 500 рублей» [1]. Они должны были оплатить проживание, питание и дорожные расходы. Но вплоть до приезда владыки Савы в Петербург (1741), из Черногории не был отправлен ни один «курьер». Было бы неверно утверждать, что поездки в Россию были невыгодны для черногорской стороны, так как известно, что владыка Сава, потративший на дорогу в Петербург более 1000 рублей, получил от российского правительства на дорожные расходы сверх этой суммы еще 200 рублей. А указ Петра I о назначении субсидии Цетинскому монастырю оставался в силе и все же исполнялся российской стороной в эпоху дворцовых переворотов. Так, в 1718 году субсидия для черногорской митрополии в 500 рублей была получена через Венецию посредством векселя, а в 1727 г. - через архимандрита Леонтия, который приехал туда «по своим потребностям» [7: с. 22].

Во время визита владыки Савы в Петербург в 1741 г. за прошедшие 23 года митрополии была выплачена сумма 5750 рублей в соответствии с указом Петра I, по которому предоставляемая Цетинскому монастырю помощь выплачивалась каждый второй год, а в каждый третий год, в который разрешался въезд в Россию, производился расчет [7: с. 22].

Хотя эта помощь предназначалась Цетинскому монастырю, она имела большое значение для всех черногорцев, так как повлияла на дальнейший ход освободительного движения и государствообразующих процессов в Черногории, где главной духовной и политической силой была Цетинская митрополия. В свою очередь сведения, получаемые российскими официальными лицами о жизни народов Балкан, имели большое значение для балканской политики России и конкретного ее проявления при разных обстоятельствах. С ростом экономического и политического могущества Российской империи ее интересы в бассейне Черного моря, на Кавказе и на Балканах непримиримо сталкивались с интересами Порты.

В войне России и Австрии против Турции 1735-1739 гг. черногорцы совершали антиосманские выступления в форме четничества. Каждый месяц отряды черногорцев вторгались на территорию Герцеговины, брали в плен турок, разоряли дома мусульман, захватывали скот, причиняя им тем самым материальный ущерб. Черногорские четы совершали налеты на торговые караваны, следовавшие в Герцег-Нови и Рисан, подрывали снабжение военных частей. Так черногорцы своими действиями отвлекали часть турецких войск [6: с. 40-42]. По окончании этой войны турки предприняли наступление против Черногории при политической поддержке Венеции. Месть османов, притеснения Венеции, поражение Австрии в войне побудили Черногорию обратиться за помощью к России.

1 сентября 1742 г. черногорские старейшины обратились к резиденту России в Стамбуле А.А. Вешнякову с просьбой о помощи. Они просили воздействовать на Порту, чтобы та никогда не воевала против черногорцев, а Черногория не платила бы ей дань. Старейшины просили добиться от султана возвращения Цетинской митрополии церквей с угодьями, захваченных турками [6: c. 114].

Однако в 1740-х гг. Россия и Турция были заинтересованы в поддержании добрососедских отношений. Россия нуждалась в сохранении мира на южных рубежах в условиях войны со Швецией (1741-1743) и для решения задач большой политики на континенте. Турция испытывала социально-экономические трудности, готовилась к войне и затем вступила в войну с Персией (1742-1746). Поэтому Вешняков в ответных письмах черногорскому митрополиту в мае 1743 г, а затем и в 1745 г. советовал черногорцам воздерживаться от антиосманских выступлений и «занимать сдержанную позицию в отношении Турции» [6: с. 115, 127-128].

В 1743-1744 гг. черногорский владыка Сава Петрович Негош в сопровождении трех старейшин вновь прибыл в Россию, чтобы получить денежную помощь, а также защиту от турецких и венецианских притязаний на Черногорию. По указу императрицы Елизаветы Петровны от 27 сентября 1743 г. владыка Сава получил 3500 рублей для Цетинского монастыря, 3000 рублей на восстановление церквей и монастырей и 1000 рублей на дорожные издержки, всего 7500 рублей. Кроме того, Сава Петрович получил от Синода церковные книги и утварь [6: с. 122].

На обратном пути из России митрополит посетил в Задаре генерального провидура Далмации и выразил ему свое расположение к Республике Св. Марка. А полученное в России золото митрополит предпочел оставить себе [10: с. 70]. Тем не менее, поездка Савы Петровича в Петербург была важным политическим шагом в процессе установления постоянных отношений между Черногорией и Россией. 
По возвращении митрополита Савы в Черногорию между ним и архимандритом Василие Петровичем, замещавшим его во время поездки в Россию, возник конфликт. Василие предпринял самостоятельные действия по улаживанию венецианско-черногорских отношений, совершив поездку в Венецию. Между архиереями развернулась борьба за власть, разделившая черногорцев на два лагеря [10: с. 79-80]. Разная внешнеполитическая ориентация архиереев только ослабляла положение Черногории перед внешним миром [4: с. 64].

В середине XVIII в. в Черногории племенная рознь превратилась в фактор, препятствующий социальноэкономическому развитию, объединению и успешному ведению освободительной борьбы против Османской империи. «Збор» каждого племени и села мог принимать самостоятельные решения, пытался наладить связи с внешним миром. Представители разных нахий (провинций), ориентируясь на Турцию, Австрию, Венецию, посылали туда своих представителей.

В августе 1750 г. преемником Савы Петровича стал Василие Петрович (1750-1766). Во внешней политике Василие Петрович стремился снизить влияние Венеции и добиться полной независимости Черногории от Порты, пытавшейся заставить Черногорию платить харач. Василие Петрович предпринял ряд поездок, которые поднимали его авторитет в глазах черногорцев и принесли материальные выгоды. По поручению печского патриарха Атанасие II в 1750 г. митрополит посетил Срем, чтобы забрать драгоценности, вывезенные из Печа в 1737 г. бежавшим патриархом Арсение IV в ходе австро-турецкой войны. Василие успешно выполнил эту задачу, но церковные богатства привез не в Печ, а в Цетине. Одновременно митрополит развивал беспорядочную внешнеполитическую деятельность. В начале 1751 г., будучи в Вене, он представил австрийскому правительству обширный меморандум с предложением установить покровительство габсбургского двора над Черногорией. На обратном пути Василие остановился в Задаре, где выразил далматинским властям готовность служить Венеции [10: с. 98, 99].

Но нараставшая угроза со стороны Турции и отсутствие помощи со стороны Венеции и Австрии побудили черногорцев вновь обратиться к России. 30 мая 1751 г. черногорский «збор» направил русскому поверенному в делах в Стамбуле А.М. Обрескову письмо с изложением трудностей Черногории. Старейшины жаловались русскому дипломату на то, что турки «все отняли», оставив черногорцам «токмо бедность и голые камни без полей и без всяких угодьев». Они просили Россию о заступничестве и предотвращении вторжения в Черногорию турецкого войска [6: с. 142-143]. О бедственном положении черногорцев еще раньше писал Обрескову и Сава Петрович.
Однако после заключения в 1747 г. новой русско-турецкой конвенции во внешней политике России Турция отошла на какое-то время на второй план. Наиболее актуальной становилась задача противодействия агрессивному усилению Пруссии. Над Европой сгущались тучи масштабной войны. В такой международной обстановке Обресков вынужден был ответить черногорцам, что в сложившихся условиях он ничего не может сделать [8: с. 141].

В мае 1752 г. в Петербург отправился Василие Петрович с верительной грамотой патриарха Атанасие II и Савы Петровича. Первый приезд Василие Петровича в Россию растянулся почти на полтора года. Пребывание в Петербурге и Москве митрополит использовал для установления личных связей со многими официальными и влиятельными лицами, стараясь расположить их к поддержке Черногории. Он писал в разные инстанции и отдельным лицам письма, прошения, меморандумы с изложением своего видения судеб Черногории. Этим целям служила книга владыки «История Черной Горы», которую он издал в 1754 г. в Петербурге с посвящением вице-канцлеру М.И. Воронцову. Пренебрегая историческими фактами и реальностью, автор представил Черногорию в расширенных границах, свободной землей, которая никогда не была завоевана турками. В этой же книге Василие Петрович высказал идею создания единого славянского государства на Балканах, в состав которого после освобождения от ига Османской империи вошли бы все славянские народы Юго-Восточной Европы. Прототипом такого государства, по мысли Василие Петровича, была средневековая Сербская держава [3: с. 179].

В апреле 1753 г. митрополит Василие обратился к канцлеру А.П. Бестужеву-Рюмину с просьбой установить покровительство России над Черногорией. Владыка пытался убедить русских официальных и влиятельных лиц в способности Черногории стать центром антиосманского движения на Балканах и выразил надежду, что в случае войны с турками к черногорцам «все окрестные славяно-сербские народы присовокупились, и отдали б себя под протекцию всероссийскую» [6: с. 186, 221]. Однако, как говорится в Записке Коллегии иностранных дел, идея подданства черногорцев России императрицей была отложена: «на каком основании часто помянутой черногорской народ ея и.в. совершенно подвластным учинен быть хочет, о том обождано будет формальное от сего народа прошение» [6: с. 197].

Тем не менее, миссия Василие Петровича в Россию оказалась успешной. 8 мая 1754 г. Елизавета Петровна издала грамоту, согласно которой кроме «милостыни» Цетинскому монастырю за 1743-1753 гг. черногорцам были пожалованы 5000 рублей «в награждение» и на восстановление разрушенных церквей, 3000 рублей на 
дорожные расходы владыке и его свите, архиерейское облачение, священнические одежды и книги. Владыке была пожалована украшенная бриллиантами панагия [6: с. 199-200]. На ходатайства Черногории оградить ее от турецкого вторжения российское правительство выразило готовность «при надежном случае» черногорскому народу «заступление учинить».

В мае 1754 г. митрополит Василие Петрович покинул Россию. По пути на родину он остановился в Вене, где получил аудиенцию у Карла VI. Очевидно, что архиерей пытался расположить и австрийское правительство в сторону Черногории.

Получив грамоты Елизаветы Петровны, черногорцы выразили благодарность императрице за поддержку, подтвердили свою готовность воевать с русскими против Турции, а также просили принять «герцегство Черногорское в протекцию российскую», установить ежегодную денежную субсидию, оказать помощь в создании училищ, воздействовать на Порту и Сенат Венеции, чтобы они «никоим образом не могли творити к умалению вольности черногорцев» [6: с. 200].

В 1758 г. в Россию прибыла черногорская депутация в составе митрополита Василие Петровича, гувернадура Станислава Радонича и черногорских старейшин. Депутация просила принять черногорцев в российское подданство, а также создать из переселившихся в Россию черногорцев особый полк, учредить для Черногории ежегодный «пенсион» до 15000 рублей и назначить русского постоянного представителя в Цетине [6: с. 225, 230-231].

Однако разыгравшийся между митрополитом Василие Петровичем и гувернадуром Станиславом Радоничем конфликт за первенство расколол черногорскую депутацию. Стороны апеллировали к русским официальным лицам, возлагая друг на друга разного рода обвинения. Эти дрязги производили неприятное впечатление в русских официальных кругах [10: с. 154-156]. Тем не менее, черногорская депутация была принята при дворе.

В знак поддержки черногорцев Елизавета Петровна издала 18 мая 1758 г. указ, по которому черногорцам посылалось 1000 золотых портретов (золотых монет с изображением императрицы), черногорские делегаты награждались золотыми медалями, продолжались выплаты им денег на содержание и были выданы им 2000 рублей на обратный путь. Митрополиту была лично пожалована 1000 рублей. Вопрос о принятии черногорцев в российское подданство представлялся императрице несвоевременным, а потому рассмотрение его откладывалось «до будущих лутчих времян». Но Елизавета обещала создание Черногорского полка, когда в Россию прибудет надлежащее число выходцев из Черногории [6: c. 221].
Императорским указом от 6 октября 1758 г. Черногории был определен ежегодный «пенсион» в 15000 рублей «для учреждения в тамошнем народе добраго порядка и приведения их в единогласие». Доставить в Цетине деньги и проконтролировать их использование было поручено советнику С.Ю. Пучкову, находившемуся тогда в Триесте в связи с переселением очередной группы черногорцев в Россию. Он также должен был ознакомиться на месте с положением черногорцев. Направить же в Цетине постоянного российского представителя императрица сочла несвоевременным [6: с. 233-234]. Пучкову также было поручено внушить представителям верховной власти Черногории, что если они постараются установить между собой порядок, согласие и дисциплину, то Черногория может рассчитывать на поддержку России и материальную помощь [3: с. 179]. Просьба депутации о выделении Россией средств до 10000 рублей ежегодно на содержание в Черногории трех полков для защиты от турецких нападений осталась неудовлетворенной. Черногорские делегаты со «слезами» объявили, что без материальной помощи на содержание полков их народ «со времянем пропадет и зделается подданным турецким, а при том и от христианства отступит» [6: c. 225].

В мае 1759 г. владыка Василие Петрович в сопровождении С.Ю. Пучкова вернулся в Черногорию. Это было первое посещение Черногории русским официальным лицом. Пучков вынес отрицательное впечатление о грубых нравах и своеволии черногорского народа, о царивших в Черногории беззаконии и анархии, а также о сребролюбии владык. Об этом он изложил в отчете, который был представлен в Коллегию иностранных дел. В своем Пучков написал, что «пользы от Черногории ожидать нечего, ибо весь сей народ нимало о службе не помышляет и по всей видимости все советы о создании Сената и Корпуса обратятся в ничто» [2].

После отъезда Пучкова владыки Сава и Василие созвали в Цетине «збор», который постановил платить Турции харач и жить в добрососедстве с Боснией, Герцеговиной и Дубровником.

Как видно из рассмотренных источников, в годы правления Елизаветы Петровны российское правительство продолжало исполнять указ Петра I по оказанию материальной помощи черногорцам, императрица лично принимала депутацию из Черногории, обеспечивая ее пребывание и компенсируя расходы. Российское правительство выделяло средства не только для поддержания Цетинского монастыря, что было обусловлено общностью религиозной традиции, но и установило ежегодный «пенсион» в 15000 рублей «для учреждения в тамошнем народе добраго порядка и приведения их в единогласие». Важным явлением стало посещение 
Черногории русским официальным лицом, предоставившим на основании непосредственного видения и личного анализа необходимую информацию о положении черногорцев. Таким образом, с российской стороны был сделан шаг для оказания помощи черногорцам и в осознании ими необходимости совершенствования своего административно-государственного и культурно-бытового устроения.

1. АВПРИ. Ф. Сношения России с Сербией. 1743. Д. 1. С. 74-76.

ЛИТЕРАТУРА

2. АВПРИ. Ф. Сношения России с Черногорией. 1762. Д. 13. Л. 20.

3. Бажова А.П. Русско-черногорские политические связи и начало государственной организации Черногории в XVIII в. // Международные отношения и внешняя политика СССР. История и современность. М.: Наука, 1977. С. 173-186.

4. Лещиловская И.И. Сербский народ и Россия в XVIII веке. СПб.: Алетейя, 2006. 297 с.

5. Орфелин 3. Житие и славные дела Петра Великого. Венеция, 1772. Ч. 2. 364 с.

6. Политические и культурные отношения России с югославянскими землями в XVIII веке. Документы. М.: Наука, 1984. 430 с.

7. Распопович Р. Первые официальные визиты черногорцев к российскому двору: миссия владыки Данилы в 1715 г. // Черногорцы в России. М.: Индрик, 2011. C. 10-28.

8. Соловьёв С.М. Сочинения. История России. М.: Мысль, 1993. Кн. 12. Т. 23-24. 687 с.

9. Станич Е. История российско-черногорских отношений в датах. М.: Вече, 2019. 352 с.

10. Станојевић Г. Митрополит Василије Петровић и његово доба (1740-1766). Београд : Историјски институт : Народна кньига, 1979. 207 с.

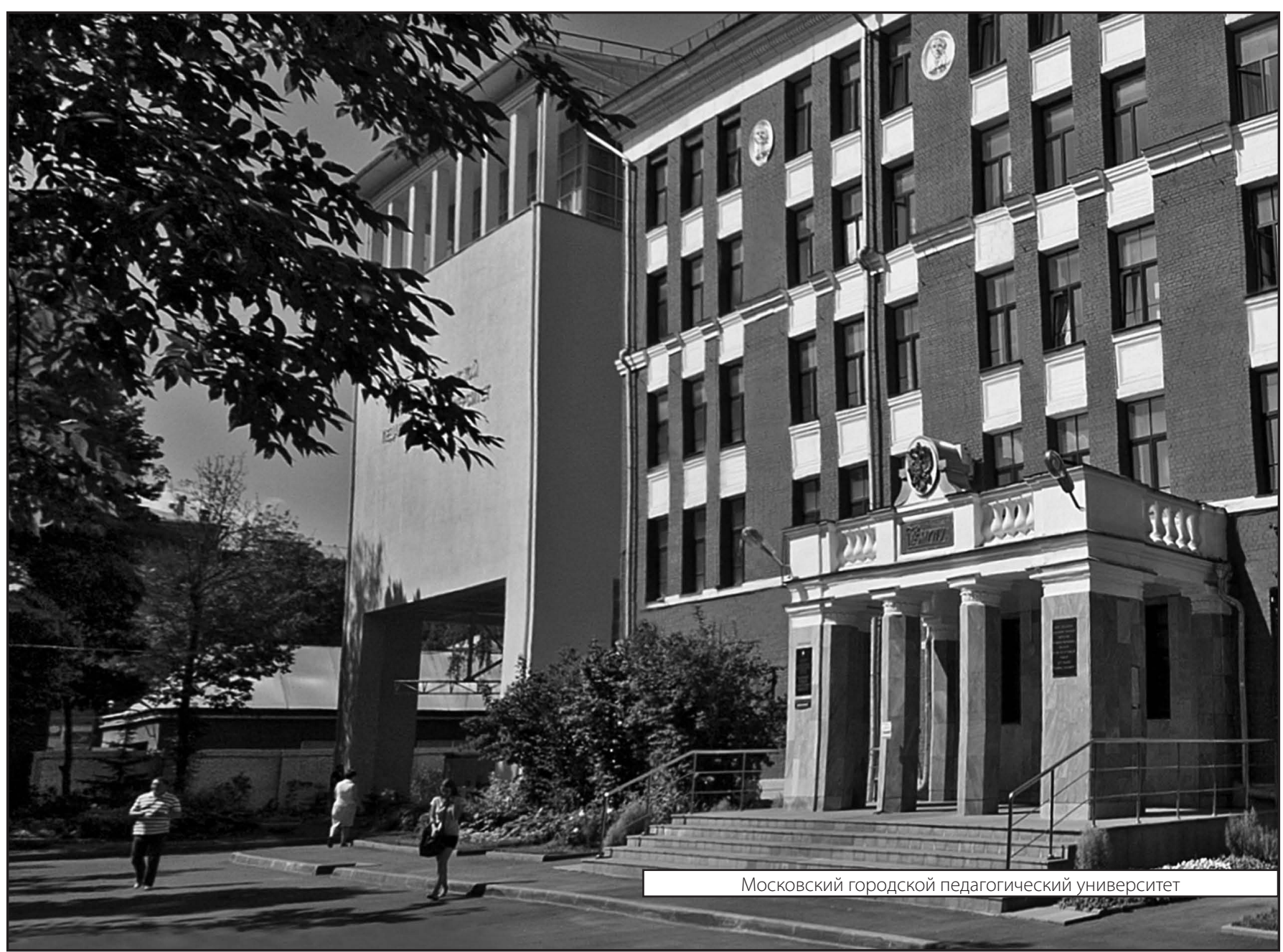

